\title{
IMPORTANT CONSTITUTIONAL QUESTIONS, NEW IN FORM, RAISED BY THE TEXAS WORKMEN'S COMPENSATION ACT ${ }^{1}$
}

The Texas Compensation Act (Texas Employers' Liability Act, Chapter I79 of the General Laws of Texas, I913, p. 429, April 16,1913 ) seeks to provide compensation for all employees who are injured and the dependents of those killed in the due course of their employment. The employers exempt from the act are those who employ five or less employees, or who are engaged in operating a cotton gin or a railway or a common carrier, or employ domestic servants, or are engaged in farming. The act creates a State Industrial Accident Board to fix the rates of premium to be paid by employers covered by the act, and to exercise general supervision over the administration of the law, and also creates the Texas Employers' Insurance Association, in which employers covered by the act are required to insure the risks covered by the statute necessary to pay their injured workmen the compensations specified by the act. This association performs its functions under the supervision of the state board.

To compel employers to insure with the association, the act abolishes the common law defenses and the fellow-servant, assumed risk, and contributory negligence rules, excepting that the jury may take into account the contributory negligence of the injured to reduce the amount of damages, where a suit lies. The association may be duly organized where twenty-five employers have qualified as subscribers. Every subscriber of the association is discharged from any common law liability on account of injury or death of any of his employees, by performing the obligations required of a subscriber by the statute. The employee of nonsubscribers who is injured, or his dependents in case he is killed, may sue his employer, who in such a case is deprived practically

\footnotetext{
1 This paper is an abstract of the brief fled by James Harrington Boyd as special counsel for The Texas Power \& Light Co., in the case of Charlie Middleton v. The Texas Power \& Light Co., Cause No. 2744, Supreme Court of Texas.

'Opinion of the Court, Charlie Middleton, Appellant, v. Texas Power \& Light Co., Appellee, No. 5408, Texas Civil Court of Appeals; same case, Supreme Court of Texas, No. 2744 .
} 
of all of his defenses, and the employee is only required to prove negligence of the employer, agent, superintendent or foreman. Wilfulness of an employee in causing his injury defeats his compensation and on the part of an employer denies him the protection of the statute.

Every subscriber of an association shall give notice in writing to all of his employees and to all of those about to enter into a contract of employment with him, that he has provided for payment of compensation for injuries with the association. Every employer who ceases to be a subscriber must, on or before the day on which his policy expires, give notice in writing to all of his employees to that effect and file a copy of the same with the Industrial Accident Board.

The principal constitutional questions raised by the Texas Compensation Act in the Middleton case, cited above, which are new in form to American jurisprudence are the following: That it violates the Constitution of the United States and the State of Texas in the following particulars:

I. The act of the employer in becoming a subscriber, in and of itself deprives the employee of life, liberty or property without due process of law;

II. The classification of employees, who work for subscribing employers and of employees who work for nonsubscribers, is not such a classification as affords the equal protection of the laws to all in the same class;

III. The act of the employer who subscribes (that is, pays to an insurance organization the premiums fixed by the state as adequate to the creation of a fund sufficient for the payment of all such as may be approved claimants against it under the law) is the exercise by a private person of authority to make law for his employees, which cannot be delegated to him by the legislature.

The specific provisions of the Texas Employers' Liability Act, which it is claimed raises the constitutional questions, the substance of which I have described above, are cited in the foot-note below. ${ }^{3}$

\footnotetext{
${ }^{3}$ In respect to the rights of all employees of employers who are not subscribers, the following provisions of said act are to be considered:

PART I.

"Section I. In an action to recover damages for personal injury sustained by an employee in the course of his employment, or for death resulting from personal injury so sustained, it shall not be a defense:
} 
The new legal questions presented, both in manner and form of raising them, by the Texas Compensation Act, new to American jurisprudence, may be defined in the following manner:

I. That the employee was guilty of contributory negligence; but in such event the damage shall be diminished in proportion to the amount of negligence attributable to such employee, provided that no such employee who may be injured or killed shall be held to have been guilty of contributory negligence where the violation by such employer of any statute enacted for the safety of the employee contributed to the injury or death of such employee.

2. That the injury was caused by the negligence of a fellow employee.

3. That the employee had assumed the risk of the injury incident to his employment; but such employer may defend in such action on the ground that the injury was caused by the wilful intention of the employee to bring about the injury.

4. Provided, however, in all such actions against an employer who is not a subscriber as defined hereafter in this act, it shall be necessary to a recovery for the plaintiff to prove negligence of such employer or some agent or servant of such employer acting within the general scope of his employment.

Section 2. The provisions of this act shall not apply to actions to recover damages for the personal injuries or for death resulting from personal injuries sustained by domestic servants, farm laborers, nor to the employees of any person, firm or corporation operating any railway as a common carrier, nor to laborers engaged in working for a cotton gin, nor to the employees of any person, firm or corporation having in his or their employ not more than five employees.

Section 4 Employees whose employers are not at the time of injury subscribers to said association and the representatives and beneficiaries of deceased employees who at the time of injury were working for nonsubscribing employers cannot participate in the benefits of said insurance association, but they shall be entitled to bring suit, and may recover judgment against such employers, or any of them, for all damages sustained by reason of any personal injury received in the course of employment, or by reason of death resulting from such injury, and the provisions of Section I of this act shall be applied in all such actions."

In respect to the rights of employees of employers who are subscribers, the following provisions of the statute are to be considered:

\section{PART I.}

"Section 3. The employees of a subscriber shall have no right of action against their employer for damages for personal injuries and the representatives and beneficiaries of deceased employees shall have no right of action against such subscribing employers for damages for injuries resulting in death, but such employees and their representatives and beneficiaries shall look for compensation solely to the Texas Employees Insurance Association as the same is hereinafter provided for; provided, that all compensation allowed under the succeeding sections herein, shall be exempt 
The compensation acts of Washington and Ohio are practically compulsory acts. Both of these acts create a state industrial commission, which is vested with the entire charge of the admin-

from garnishment, attachment and all other suits or claims, as are current wages now exempted by law."

PART III.

(Notices required to be given to employees of subscribers and others by subscribers.)

"Section 19. Every subscriber shall, as soon as he secures a policy, give notice, in writing or print, to all persons under contract of hire with him that he has provided for payment of compensation for injuries with the association.

Section 20. Every subscriber shall, after receiving a policy, give notice in writing or print, to all persons with whom he is about to enter into a contract of hire, that he has provided for payment of compensation for injuries by the association. If any employer ceases to be a subscriber, he shall, on or before the day on which his policy expires, give notice to that effect in writing or print to all persons under contract of hire with him. In case of the renewal of his policy no notice shall be required under this act. He shall file a copy of said notice with the Industrial Accident Board."

General provisions of the statute affecting both subscribing employers and non-subscribing employers and the employees of both classes of employers :

PART I.

(Respecting wilful and gross negligence, whether of a subscribing or non-subscribing employer.)

"Section 5. Nothing in this act shall be taken or held to prohibit the recovery of exemplary damages by the surviving husband, wife and heirs, or such of them as there may be, of any deceased employee whose death is occasioned by homicide, through the wilful act or omission or gross negligence of any person, firm or corporation, the employer of such employee at the time of the injury, causing the death of the latter, and in all cases where exemplary damages are sought under this section, in case the injured party has already been awarded actual damages by the Board herein provided, said fact and said amount so received shall be made known to the court or jury trying said cause for exemplary damages; and on the issue for exemplary damages he shall have the same defenses as under the existing law."

PART II.

(Respecting the settlement of disputes.)

"Section 5. All questions arising under this act, if not settled by agreement of the parties interested therein, shall, except as otherwise herein provided, be determined by the Industrial Accident Board. Any interested party who is not willing, and does not consent to abide by the final ruling and decision of said board on any disputed claim may sue on such claim or may require suit to be brought thereon in some court of competent 
istration of the acts, and the entire cost of administration, including the salaries of commissions, is paid from the general fund of the state treasury.

The Washington act abolished the common law action as a basis for compensating injuries to workmen arising out of the due course of their employment in forty-eight classes of employments classified in the statute with corresponding rates of premium fixed therein. The Washington Industrial Commission calls these premiums as needed, receives notices of accidents, determines the extent of the injuries and makes the awards of compensation. It prosecutes employers, coming within the classes fixed by the statute, who fail to comply with its provisions.

The Ohio act affects all employers who employ five or more operatives, employees of the state, counties, cities, townships, and school districts (excepting firemen and policemen who are protected by funds provided by cities). It creates a state industrial commission which classifies the employments, fixes the rates of premiums and collects the same, determines the extent of the injuries and makes the awards of compensation, which are paid from the state insurance fund created by the accumulation of said premiums contributed by the employers only.

When the employer has paid the premiums fixed by the commission he is discharged from any common law liability on account of any injury to or death of any employee arising out of his employment, excepting where the cause of the injury is due to the violation of a statute regulating the safety of the employee by the employer, his agent, superintendent or foreman.

In case an employer covered by the act does not pay the premiums fixed by the commission, an injured employee, or in case of death of the same, the employee's dependents may sue his employer, who loses all the common law defenses, or he may have an award made for compensation under the act, and if the award is not paid within ten days, it becomes a lien like unpaid taxes.

jurisdiction, and the board shall proceed no further toward the adjustment of such claim: Provided, however, that whenever any such suit is brought, the rights and liabilities of the parties thereto shall be determined by the provisions of this act, and the suit of the injured employee, or persons suing on account of the death of such employee, shall be against the association, if the employer of such injured or deceased employee is at the time of such injury or death a subscriber, as defined in this act, in which case the recovery shall not exceed the maximum compensation allowed under the provisions of this act, and the court shall determine the issues in such cause instead of said board." 
All of the constitutional questions raised by the Washington act have been sustained in favor of the act by the Supreme Court of Washington. ${ }^{4}$

All of the constitutional questions raised by the Ohio act have been sustained in favor of the act by the Supreme Court of Ohio and the United States Supreme Court. ${ }^{5}$

But the Texas act is a radical departure from either of these plans. Here the injured worker's claim for compensation is against a fund accumulated by premiums fixed by a state commission, but the fund is administered by an association of employers which determines the extent of an injury and the amount of compensation, subject to the supervision of the Texas Industrial Accident Board, as provided for in Part II of the act.

ECONOMIC CONSIDERATIONS. PURLIC BENEFITS CONFERRED BY THE TEXAS WORKMEN'S COMPENSATION ACT

That the Texas legislature is vested with the right by enactment of the Texas Employers' Liability Act, cited above, to abolish the common law defenses, fellow-servant rule, rule of the assumed risk and rule of contributory negligence (with the doctrine of comparative negligence introduced), has been settled beyond dispute by the supreme courts of many states of the United States, and by the Supreme Court of the United States. ${ }^{\text {a }}$

A matter of vital importance in considering this question is, what is the magnitude of the economic benefits conferred upon workmen covered by the act by the abolition of these defenses?

The effect of abolishing these defenses is that it doubles and trebles the amount of compensation which injured and dependents of killed workmen, as a class receive, by doubling and trebling their chances of recovery.

Before highly efficient means had been introduced for prevention of accident (in Germany up to 1887) you could attribute the cause of accidents to the employers in about 20 per cent. of

\footnotetext{
State v. Clausen, ir7 Pàc. Iror.

'State ex rel. Yaple v. Cramer, 85 Ohio St. 349; Jeffrey Mfg. Co. ข. Blagg, 235 U. S. 571.

Sate v. Clausen, 66 Wash. 156; State ex rel. Yaple v. Cramer, 85 Ohio St. 349; Borgnis v. Falk Co., I47 Wis. 327; Cunningham v. Northwestern Improvement Co., 44 Mont. I08; Sexton v. Newark District Telegraph Co., 86 Atl. (N. J.) 45I; Mondu v. New York, N. H. \& H. R. Co., 223 U. S. I; Opinion of Justices of Massachusetts, 209 Mass. 607 ; and the numerous decisions cited therein.
} 
the cases. ${ }^{b}$ But when the defenses were all in operation a recovery could not be had in to exceed 8 per cent. of the cases and in Ohio less than 6 per cent. of the cases. ${ }^{7}$

The abolition of the fellow-servant and contributory negligence rules alone permits recoveries in Io per cent. of the cases. ${ }^{7}$ and 6

The economic benefits conferred upon the workmen as a class by depriving injured workmen, employed by a subscriber, of the common lawe right of action to recover on account of any personal injury (whether maimed or killed) is very much greater than that of abolishing said defenses.

The first effect is that all injured employees who are employed by members of the association receive substantial compensation, whereas those who sue, looked at as a whole, will not recover in to exceed 20 per cent. of the cases, even though all of the defenses were abolished and experience shows it to be much less. ${ }^{8}$ And these 20 per cent. will not receive on the average as high compensation as they would receive under the Texas Employers' Insurance Association (or the Ohio act which, as regards compensation, is about the same as the Texas act).

Consider death cases under the Ohio act. In the first IO2 cases the awards amounted to 274,069 , varying in amount where there were dependents from $\$ 1000$ to $\$ 3744$. In addition to this, in each case there were paid all of the doctor bills, hospital bills and funeral expenses. That is, the average death award was \$2687. Previous to the passage of the Ohio Compensation Act, there was paid in death cases something in only 36 per cent. of the cases where dependents were left and nothing was paid in 64 per cent. of the cases, and the average amount paid was only $\$ 836.6 \mathrm{I}$, which included doctor bills, funeral expenses and burial expenses. ${ }^{\circ}$

Then, too, in this connection the fact that causes, exclusive of the employer's negligence, constitute 80 per cent. of all causes of accidents should be considered. ${ }^{10}$ So that, in the case cited above of the IO2 workmen killed, the public benefit conferred under the Ohio act over the right to recover under the common law would be 80 per cent. of $\$ 274,069.80$, or $\$ 219,255$, and it would be equally as large under the Texas act.

\footnotetext{
'Economic Basis of Workmen's Compensation Acts, Mich. Law Review, March, 19r2, p. 345, and following.

${ }^{7}$ Report of Employer's Liability Commission of Ohio (IgII) p. 60

sulletin of the Industrial Commission of Ohio, Vol. I, No. 2 (June Ist, 1914), pp. 20 to 32.

${ }^{\circ}$ Report Employer's Liability Commission of Ohio, Part I, p. XXXVIII.

${ }^{10}$ Same Report, p. XXIX, Table (a), first column, and note "6" above.
} 
The Ohio act is as compulsory in form as can be had in practice. This compulsion or penalty for compelling compliance with the act is provided in Sections 26 and 27 ( 103 Ohio Laws, 82). If an employer does not pay the premiums required by the law under Section 26 , the injured worker may sue his employer, who will have lost all his defenses; or he may proceed under Section 27, and have the State Industrial Commission make the award in the same manner as though the employer had paid the premiums, and the award; if not paid within ten days, becomes a liquidated claim of the same nature as a judgment for unpaid taxes.

The compulsion provided in the Texas act to compel the employers to insure in the association is about as great as it is under the Ohio act. There are $1,000,000$ workmen and $2,000,000$ dependents of workmen under the protection of the Ohio act at the end of two years out of a population of $5,000,000$, and within the same time a corresponding protection for the workmen will exist in Texas.

The Texas act also throws the cost of administering the Texas Compensation Act upon the employers direct, whereas, under the Ohio act (also Washington act) the costs, which annually amount to about $\$ 150,000$, are paid out of the general fund of the state.

\section{VALIDITY OF THE TEXAS EMPLOYERS' LIABILITY ACT AS AFFECTING EMPLOYEES OF SUBSCRIBERS TO THE ASSOCIATION}

The act takes away absolutely from him his common law right of action against his employer, who is a subscriber, for non-fatal injuries cansed by the employer's negligence. As to fatal injuries, a cause of action against an employer was unknown to the common law, is a statutory creation, and consequently (since the constitution of the state contains no inhibition) is subject without question to repeal by the legislature. The act carefully saved any right of action on account of an injury received prior to the date named for it to become operative, upon the employers and employees affected by it. The question involves not the taking away of a vested right of action, but the changing of the law in respect of expectancies and possibility of action in which the party has no present interest.

Judge Cooley in his work on Constitutional Limitations, pages 438 et seq., says: "Vested rights cannot be taken away by legislative enactments, but a right cannot be considered a vested right unless it is something more than such a mere expectation as may 
be based upon the anticipated continuance of the present general laws. The legislature may change such general laws constitutionally except as to a right of interest that may have already accrued or become perfected. . . . In organized society every man holds all he possesses and looks forward to all he hopes for through the aid and under the protection of the laws; but as changes of circumstances and public opinion, as well as other reasons affecting the public policy, are all the while calling for changes in the laws, and as these changes must influence more or less the value and stability of private relations and strengthen or destroy well-founded hopes, and as the power to make very many of them could not be disputed without denying the right of the political community to prosper and advance, it is obvious that many rights, privileges and exemptions that usually pertain to ownership under a particular state of law, and many reasonable expectations, cannot be regarded as vested rights in any sense."

The Supreme Court of the United States in Munn v. Illinois ${ }^{11}$ said: "But a mere common-law regulation of trade or business may be changed by statute. A person has no property, no vested interest, in any rule of the common law. That is only one of the forms of municipal law, and is no more sacred than any other. Rights of property which have been created by the common law cannot be taken away without due process; but the law itself, as a rule of conduct, may be changed at the will or even at the whim of the legislature, unless prevented by constitutional limitations. Indeed the great office of statutes is to remedy defects in the common law as they are developed, and to adapt it to the changes of time and circumstances."12

In the Ives Case, ${ }^{13}$ the court said: "The legislature may alter or repeal the common law. It may create new offenses, enlarge the scope of civil remedies, and fasten the responsibility for injuries upon persons against whom the common law gives no remedy," the language being a quotation from the decision of the court of appeals in the Berthold Case.

Some of the states embody in their constitutions, in substance, the provisions of Magna Charta: "Every man shall have a remedy

${ }^{11} 94$ U. S. 113,24 L. ed. 77.

12 Applied to the relation of master and servant in Vindicator Consol. Gold Mirt. Co. v. Firstbrook, 36 Colo. 498, 86 Pac. 313, 1o Am. \& Eng. Ann. Cas. 1108.

${ }^{13} 68$ Misc. 643, I24 N. Y. Supp. 920. 
for injury done him in person, property, or reputation." Nevertheless, the principle last above stated has been sustained in states having such a constitutional provision. For example, in Templeton v. Linn County," the Supreme Court of Oregon said: "The words 'and every man shall have a remedy by due process of law for injury done him in person, property or reputation, are claimed to operate as a guaranty in favor of all persons who might be injured by a county's neglect, that the legislature should never so change the statute as to destroy the liability of such county. In other words the constitution found a certain liability created by statute resting upon the several counties, and tied the hands of the legislature, so that such liability should endure as long as the constitution shall remain in force. As a proposition of constitutional law, the contention seems startling, and, although the constitutions of many of the states of this Union contain substantially the same provisions as Sec. Io, supra, no judicial authority was cited upon the argument in support of it, and I think it may be safely assumed that none exists. . . . . At the time of the repeal the plaintiff had no cause for action against Linn county, and her sole cause of complaint is that the repeal of the statute before the injury cut off a cause of action which she would have otherwise had against the county ... Vested rights are placed under constitutional protection, and cannot be destroyed by legislation. Not so with those expectancies and possibilities in which the party has no present interest."

In Williams v. Galveston, ${ }^{15}$ the court said: "The citizen has no property right in a rule of law, and, while rights may accrue to him under the operation of a legal rule, which become vested and cannot be taken away from him by the change of the rule, he cannot be heard to complain if, before such property rights became vested, the rule is so changed that no rights can accrue thereunder."

So also in Saroyer v. El Paso \& N. E. R. Co., ${ }^{16}$ involving the constitutionality of a statute providing that no action could be brought for personal injuries unless a certain kind of affidavit was served within ninety days, the court said: "Conceding that a cause of action for personal injuries is property, the cause of action, i. e., the property, must exist before one can be deprived of it at all. A statute which abrogates a cause of action for per-

is 22 Or. 313, 5I L. R. A. 730, 29 Pac. 795.

${ }^{25} 4 \mathrm{I}$ Tex. Civ. App. 63, 90 S. W. 505.

${ }^{16} 49$ Tex. Civ. App. 106, 108 S. W. 718. 
sonal injury before such cause of action has arisen or before the injury occurs, or requires certain things to be done by the injured party as conditions precedent to a cause of action, does not deprive the injured party of his property rights without due process of law. . . I In other words, the legislature may create a right of action which never existed, if in doing so it does not affect rights which vested prior thereto. $A$ party injured after the legislature has taken away the right of action for personal injuries can no more complain of it than a party against whom a right of action is given for an injury resulting in death can of such a le gislative enactment. For the one party is no more injuriously affected by such legislation than the other. In the same case what was before actionable ceases to be so; in the other, what was not before actionable becomes so."17

It was through the guidance of the principles set forth in the foregoing discussion, and the necessity of abandoning the old common law remedy for compensating personal injuries as shown under the economic considerations set forth above and in authorities there cited, that I drafted provisions in the Ohio Workmen's Compensation Act which read as follows:

Section 20-1. Any employer who employs five or more workmen or operatives regularly in the same business, or in or about the same establishment, who shall pay into the state insurance fund the premiums provided by this act, shall not be liable to respond in damages at common law or by statute, save as hereinafter provided, for injuries or death of any such employee, wherever occurring, during the period covered by such premiums, provided the injured employee has remained in his service with notice that his employer has paid into the state insurance fund the premiums provided by this act; the continuation in the service of such employer with such notice, shall be deemed a waiver by the employee of his right of action as aforesaid.

Each employer paying the premiums provided by this act into the state insurance fund shall post in conspicuous places about his place or places of business typewritten or printed notices stating the fact that he has made such payment, and the same, when so posted, shall constitute sufficient notice to his employees of the fact that he has

\footnotetext{
${ }^{17}$ Other important cases in support of the main proposition stated immediately above are: Kirby 2. Pennsylvania $R$. $R$. Co., $76 \mathrm{~Pa}$. 506; Martin v. Pittsburg \& L. E. \& R. Co., 203 U. S. 284; Middleton v. Fowler, I Salk. 282; Gray v. Portland Bank, 3 Mass. 364; Harlow v. Humiston, 6 Cow. 189 .
} 
made such payment; and of any subsequent payments he may make after such notices have been posted.

Section 2I-I. All employers who employ five or more workmen or operatives regularly in the same business, or in or about the same establishment who shall not pay into the state insurance fund the premiums provided by this act, shall be liable to their employees for damages suffered by reason of personal injuries sustained in the course of employment caused by the wrongful act, neglect or default of the employer, or any of the employer's officers, agents, or employees, and also to the personal representatives of such employees where death results from such injuries and in such action the defendant shall not avail himself or itself of the following common law defenses:-The defense of the fellow-servant rule, the defense of the assumption of risk, or the defense of contributory negligence.

Section 2I-2. But where a personal injury is suffered by an employee, or when death results to an employee from personal injuries while in the employ of an employer in the course of employment, and such employer has paid into the state insurance fund the premium provided for in this act, and in case such injury has arisen from the wilful act of such employer or any of such employer's officers or agents or from the failure of such employer, or any of such employer's officers or agents, to comply with any municipal ordinance or lawful order or any duly authorized officer, or any statute for the protection of the life or safety of the employees, then in such event, nothing in this act contained shall affect the civil liability of such employer, but such injured employee, or his legal representative in case death results from the injury, may, at ${ }^{\circ}$ his option, either claim compensation under this act or institute proceedings in the courts for his damage on account of such injury, and such employer shall not be liable for any injury to any employee, or to his legal representatives in case death results, except as provided in this act.

Every employee, or legal representative in case death results, who makes application for an award from the state liability board of awards, waives his right to exercise his option to institute proceedings in any court. Every employee or his legal representative in case death results, who exercises his option to institute proceedings in court as provided in section $2 \mathrm{I}-2$, waives his right to any award; except as provided in section 36 of this act. ${ }^{18}$

These provisions of the Ohio act raise the same constitutional questions as those stated in propositions I and II, stated above, and raised by the provisions of the Texas Employers' Liability Act.

\footnotetext{
${ }^{18}$ Laws of Ohio, I02 (IgII), pp. 528 and 529.
} 
The fact that the Ohio act provides that the employers pay the premiums into the state treasury under the supervision of the State Liability Board of Awards, whereas the Texas act requires the employers to pay the premiums under the supervision of the Texas Employers' Insurance Association, which is under the supervision of the Texas Industrial Accident Board, does not alter the nature of the constitutional questions raised. Such a policy, whether it take the one form or the other, is wholly within the authority of the legislatures.

The provisions of the Ohio act were sustained in the case, State of Ohio ex rel. Yaple v. Cramer, 85 Ohio St. 349.

The same objections were urged against the provisions of the Ohio act as are urged against the above provisions of the Texas act, and especially urged by the Texas Court of Appeals. The Ohio Supreme Court, in disposing of these questions, says at pp. 393-397, in Yaple v. Cramer:

"As to the employee, if the parties do not elect to operate under the act, he has his remedy for the neglect, wrongful act or default of his employer and agents as before the law was passed, and is not subject to the defenses named.

If the parties are operating under the act the employee contributes to an insurance fund for the benefit of himself or his heirs, and in case he is injured or killed, he or they will receive the benefit even though his injury or death was caused by his own negligent or wrongful act, not wilful. And that is not all. Under Section $2 \mathrm{I}-2$ if the parties are operating under the act and the employee is injured or killed, and the injury arose from the wilful act of his employer, his officer or agent, or from failure of the employer or agent to comply with legal requirements, as to safety of employees, then the injured employee or his legal representative has his option to claim under the act or sue in court for damages.

Therefore the only right of action which this statute removes from the employee is the right to sue for mere negligence (which is not wilful or statutory) of his employer, and it is within common knowledge that this has become in actual practice a most unsubstantial thing. It is conceded by counsel that the particulars named in Section $2 \mathrm{I}-22$ are such as form the basis for a large portion of claims for personal injuries.

On account of the common law and statutory rights still preserved to the parties by this statute in cases where the election is made to come under its provisions as well as not to do so taken in connection with the advantage to each 
which the plan contemplates, we cannot say that the statute is coercive. As was said in the Wisconsin case: 'Laws cannot be set aside upon mere conjecture or speculation. The court must be able to say with certainty that an unlawful result will follow.' We do not see how any such thing can be said here. Every consideration of prudence and self interest (things not easily associated with compulsion and coercion) would seem to lead an employee to voluntarily make the contribution and waiver contemplated. Second. Does this Statute take private property without due process of law and deny the guaranties of the constitution as claimed?

Perhaps no exact definition of 'Due process of law' has been agreed upon. Judge Story defines it in his work on the constitution, Section I935: "The right to be protected in life, and liberty and in the acquisition of property under equal and impartial laws, which govern the whole community. This puts the state upon its true foundation, for the establishment and administration of general justice, justice of law, equal and fixed, recognizing individual rights, and not impairing them.' In Cooley on Const. Limit., Sec. 356, it is said: 'Due process of law in each particular case, means such an exercise of the government as the settled maximums of the law permit and sanction, and under such safeguards for the protection of individual rights as those maxims prescribe for the classes of cases to which the one in question belongs.'

The case of Ives v. South Buffalo Ry. Co., 201 N. Y. 276 (relied on by some of counsel), involved a statute different in many essentials from the Ohio law. Its controlling feature was that every employer engaged in any of the classified industries should be liable to a workman for injury arising in the course of the work by a necessary risk inherent in the business whether the employer was at fault or not and whether the employee was at fault or not, except when his fault was wilful.

The court held the law invalid, as imposing the ordinary risks of a business (which under the common law the employee was held to assume) on the employer.

As to the right to abolish the defense of assumption of risk, it is enough to say here that the great weight of authority is against the New York position and the position of such of the counsel in this case as insist on that rule. Some of the counsel appearing against the validity of this law, concede the right to abolish the defenses referred to. The supreme courts of Massachusetts, Wisconsin and Washington have recently held in cases sustaining the validity of statutes similar to the one here attacked, that it is within the legislative power to abolish 
the defense referred to. In re Opinion of Justices, 209 Mass. 607, 96 N. E. 308; Borgnis v. Falk Co., I47 Wis. 327, I33 N. W. 209; State ex rel. v. Clausen, 65 Wash. I56, II7 Pac. IIOI.

Since the argument of this case the Supreme Court of the United States has decided the case of Mondon $v$. New York, N.H. \& H.R. Co., 223 U. S. I, and has sustained the constitutionality of the employers' liability law passed by Congress. The abolition of these rules was urged as an objection to the law. The court say:

'Of the objection to these changes it is enough to observe:

First. A person has no property, no vested interest, in any rule of the common law. That is only one of the forms of municipal law, and is no more sacred than any other. Rights of property which have been created by the common law cannot be taken away without due process; but the law itself, as a rule of conduct, may be changed at the will ... of the legislature, unless prevented by constitutional limitations. Indeed, the great office of statutes is to remedy defects in the common law. as they are developed, and to adapt it to the changes of time and circumstances. Munn v. Illinois, 94 U. S. Ir3, I34; Martin v. Pittsburg \& Lake Erie R. R. Co., 203 U. S. 284, 294; The Lottawanna, 2I Wall, 558, 577; Western Union Telegraph Co. v. Commercial Milling Co., 2I8 U. S. 406, 4I7.'"

In view of the great public benefits conferred by the said provisions of the Texas Employers' Liability Act presented above, we call attention to the long established principle:

"It is almost an axiom that anything which is reasonable and necessary to secure the peace, safety, morals and best interests of the commonwealth may be done under the police power; and this implies that private rights exist subject to the public welfare. These principles are plainly recognized in Article XIV, Section I, of the Constitution of the United States, and Article r, Section I9, of the Constitution of Ohio."19

THE SO-CALIED CLASSIFICATION OF EMPLOYEES BY THE TEXAS COMPENSATION ACT

This classification of employees, if indeed it may be called such, into two classes, as stated in proposition II above, namely, employees who work for subscribing employers, and employees

\footnotetext{
${ }^{19}$ Phillips v. State, 77 Ohio St. 216.
} 
who work for employers who have not qualified as subscribers, does not violate the state or federal constitutions which guarantee the equal protection of the laws to all citizens.

That this is true follows as a mere matter of logic. For, the employee of a subscriber has "no property, no vested interest, in any rule of common law." It has been shown above that the legislature has the right to take away the common law action for personal injuries. ${ }^{20}$

The manner in which the legislature of Texas may see fit to do this is immaterial, especially where it confers greater and new benefits on the public by providing certain new and enlarged benefits to the injured workers. The legislature could not give the employers of subscribers both universal and increased compensations and preserve for him his common law right of action or create a right in him giving a choice between the two. This was attempted in the Montana Act. ${ }^{21}$

The great social problem here under consideration cannot be solved in any other way except in the way Washington, Ohio, Texas-and Germany have done it!

The classification here under consideration comes within the rule laid down by the Supreme Court of the United States on January 5th, I9I5, when that court settled the last effort to attack the constitutionality of the Ohio Compensation Act. ${ }^{22}$ The court, in disposing of this question, said:

"The fact that the negligence of a fellow servant is more likely to be a cause of injury in the large establishments, employing many in their service, and that assumed risk may be different in such establishments than in smaller ones, is conceded in argument, and is, we think, so obvious that the state legislature cannot be deemed guilty of arbitrary classification in making one rule for large and another for small establishments as to these defences.

The question now is: Are employers who fail to come into the plan of the statute by complying with its requirements, who employ five men or more, arbitrarily discriminated against, because of the provisions of the act which deprive them of the benefit of the defense of contributory negligence of the employee, while the smaller

${ }^{2}$ Mondon v. New York, N. H.\& H. R., 223 U. S. I; State v. Clausen, 69 Wash. 156.

${ }^{21}$ Cusningham v. Northzestern Imp. Co., 44 Mont. Io8.

${ }^{2}$ Jeffrey Manufacturing Co., v. Blagg, 235 U. S. 57 I. 
émployers, employing four or less, may still find such defense available?

This court has many times affirmed the general proposition that it is not the purpose of the I4th Amendment in the equal protection clause to take from the states the right and power to classify the subjects of legislation. It is only when such attempted classification is arbitrary and unreasonable that the court can declare it beyond legislative authority. . . . Classifications of industry with reference to police regulations, based upon the number of employees, have been sustained in this court.

Certainly in the present case there has been no attempt at unjust and discriminatory regulations. The legislature was formulating a plan which should provide more accurate compensation to the beneficiaries of those killed and to the injured in such establishments, by regulating concerns having five or more employees.

We are not prepared to say that this act of the legislature, in bringing within its terms all establishments having five or more employees, including the deprivation of the defense of contributory negligence where such establishments neglect to take the benefit of the law, and leaving the employers of less than five out of the act was classification of that arbitrary and unreasonable nature which justifies a court in declaring this legislation unconstitutional."

The foregoing principles of classification of subjects are applicable to the classification of employees by the Texas Employers' Liability Act. This is unimpeachably so when you consider the following. The Supreme Court of the United States in the case, The St. Louis Consolidated Coal Co. v. Illinois, I85 U. S. 203, sustained the provision of the mine inspection act which provided that the mine operators should be charged with the cost of inspection of the mines owned and operated by them. This decision sustains the right of the Texas legislature to create the Texas Employers' Insurance Association, and to charge the employers insured by it with the cost of the administration of the insurance system, which of necessity carries with it the plan of classification of employees we are here discussing.

The Illinois statutes referred to provided : ${ }^{23}$

"Sec. IId. Any person, company or corporation operating any coal mine in this state shall be required to pay an

\footnotetext{
${ }^{23}$ Hurd's Statutes, 1897, page ro88, C. 93.
} 
inspection fee of not less than six dollars nor more than ten dollars for each visit of inspection or investigation of a coal mine by a state mine inspector, such fee to be regulated by the class of the mine, which shall be fixed by the inspector and depend upon the length of time consumed, and the expense necessarily incurred in the inspection of such mine, and such fees shall be paid quarterly by the person, company or corporation operating the mine inspected to the secretary of the Bureau of Labor Statistics and by him covered into the state treasury to be held as a fund for the payment of salaries of State Mine Inspectors, as herein provided."

The Supreme Court of the United States in sustaining this provision of the Mine Inspection Act of the State of Illinois in its opinion dated April 14, 1902, held:

"It is within the power of a state legislature to provide for the appointment of inspectors of mines and the payment of their fees by the owners of the mines."

The entire opinion in this case is applicable and should be read in connection with the questions raised by propositions I, II.

It is wholly within the province and power of the State of Texas to determine the nature of the penalty which in view of the general public welfare should be imposed upon employers amenable to the Texas Employers' Liability Act in order to make them comply with the act and insure their employees with the Texas Employers' Insurance Association.

The legislature has a right to take away the defenses of a nonsubscriber to the extent that it did in Part I, Sec. I of said act, or it might have taken away absolutely all of the defenses as did the legislatures of Ohio and Massachusetts, or it might have done as the legislature of Washington did, take away the entire common law right of action.

If the State of Texas had done what the State of Washington did, and Ohio did in effect, taken away the common law right of action in place of Sec. I, Part I, then there would be only one class of employees, namely, those of subscribing employers only. Thus it is evident as a matter of logic under the acknowledged right of the Texas legislature, that it is purely discretionary on its part how severe the penalty shall be, and it may compel all employers amenable to the Texas Employers' Liability Act to become subscribers. 
The constitutional question involved in proposition III, namely, that "The act of the employer who subscribes (that is, pays to an insurance organization the premium fixed by the state as adequate to the creation of a fund sufficient for the payment of all such as may be approved claimants against it under the law) is the exercise by a private person of authority to make law for his empioyees, which cannot be delegated to him by the legislature," the court below in its opinion stated as follows:

"The Constitution (Texas) also vests in the legislature the exclusive power to make laws, and therefore that body has no power to delegate legislative authority to any private person. Undoubtedly the statute here involved is optional as to the employer; he has his choice and may or may not become a subscriber, pay premiums, obtain insurance for the benefit of his employees, and thereby release himself from what would otherwise be his liability to such employees. It is true that if he does not pursue that course he loses some of his common law defenses, but the fact remains that he has an option, and may choose between two laws concerning himself and his employees, and fixing their respective rights."

The provisions of the Texas Employers' Liability Act here referred to, violate no provision of the Federal or Texas Constitution.

It is admitted by all eminent students of this question that the old common law remedy for compensating personal injuries based upon negligence must be abandoned, ${ }^{24}$ and a new remedy substituted therefor. The legislature of Texas is vested with the right to determine the nature and policy of the new.remedy.

All civilized countries have long since abandoned the old barbaric common law remedy. In the United States compensation acts have been passed in twenty-two states. Of these the acts of the States of Washington and Ohio are so called drastically compulsory, the element of option on the part of both employer and employee being practically eliminated. The Ohio and Washington acts are most successful. They have been endorsed by both the associations of workmen and employers in each state; a state board levies the premium, makes the award to the injured, and has complete control of the entire administration of the acts.

The legislature of Texas vested their administration in two boards: the State Industrial Accident Board and the Texas

\footnotetext{
${ }^{24}$ Economic and Legal Basis of Compulsory Industrial Insurance for Workmen, Michigan Law Review, March, Igr2.
} 
Employers' Insurance Association, in such a way as to throw on to the employers the entire cost of administration of the law, but in Washington and Ohio the cost of administration of the acts is paid out of the State Treasury. There is a similar provision in the French, German and other laws in Europe. .

While under the Texas act, which eliminates largely the defenses, the workmen who sue may recover in twenty per cent of the cases, death cases will not average over all to exceed five hundred dollars $(\$ 500.00)$. But under the association scheme the average compensation in death cases will be about as high as in Ohio and Washington, which is about $\$ 2,675$ plus funeral expenses, etc. ${ }^{25}$

Under the German Law the Association of Employers has entire charge of the paying of premiums and payments of compensation, excepting that representatives of employees and the government take part in determining the extent of the injuries. The German Industrial Insurance Law distributes every year $\$ 250,000,000$ to the dependents of the sick, injured and old age pensions. There $22,000,000$ workmen and dependents are protected by the law.

Shall the Supreme Court of Texas say to the people of Texas, that Texas can not have as humane a law as Germany under Prince Bismarck?

The removal of the defenses should be looked upon as a penalty imposed upon all the employers who fail to pay their premiums and join the association. It is evidently to the general public's good that all employers should be members of the association and the dependents of all workers receive adequate compensation to prevent them from becoming public charges.

It is fully within the discretion of the legislature as to what this penalty shall be. Within the next year or two the legislature may decide to make the penalty more burdensome and as much so or greater than provided for by the Washington and Ohio acts.

The Texas act (Part I, Section 3, Part III, Section I7), which provides that where an employer pays to an insurance organization the premium fixed by the state as adequate for the creation of a fund sufficient for the payment of all such compensation as may be approved by claimants against it under the law, does not confer legislative or judicial power either upon the employer, the

\footnotetext{
${ }^{2}$ Michigan Law Review, March, I9I2.
} 
Industrial Accident Board or the Texas Employers' Insurance Association, nor deprive the employee of recourse to the courts. The legal nature of such provision in this respect is clearly set forth in the following, quoting from Yaple v. Cramer, 85 Ohio St. 401 , where the court discusses these questions:

"We do not consider the Board of Awards a court, or invested with judicial power within the meaning of the constitution.

It is created by the act purely as an administrative agency to bring into being and administer the insurance fund, and the fact that it is empowered to classify persons who come under the law and to ascertain facts as to the application of the fund, does not vest it with judicial power within the constitutional sense.

In State ex rel. $v$. Hawkins, 44 Ohio St. 98, it is said: 'What is judicial power cannot be brought within the ring-fence of a definition. It is tundoubtedly power to hear and determine, but this is not peculiar to the judicial office. Many of the acts of administrative and executive officers involve the exercise of the same power.' The court then shows that many boards hear and determine questions affecting private as well as public rights, and quotes with approval from State ex rel. v. Harmon, 31 Ohio St. 250: 'The authority to ascertain facts and apply the law to the facts when ascertained pertains as well to other departments of government as to the judiciary.'

Does the law deny recourse to the courts and trial by jury?

How does it affect an injured employee where the parties are operating under the act? In B. \& O.Rd. Co. v. Stankard, 56 Ohio St. 232, which was a suit by the beneficiaries of a member of the relief department of the railroad, the company answered setting up a rule which provided that the decision of the relief department should be final. The court say: 'The right to appeal to the courts for redress of wrongs is one of those rights which in its nature under our constitution is inalienable and cannot be thrown off or bargained away.'

But the court shows that parties may contract to submit the fixing of facts to some non-judicial tribunal and say: 'In insurance and other like cases where the ultimate question is the payment of a certain sum of money, certain facts may be fixed by a person selected for that purpose in the contract, but the ultimate question as to whether the money shall be paid or not may be litigated in the courts and a stipulation to the contrary is void. 
So that under that rule the parties may conclusively bind themselves in advance to submit questions of amount, etc., to some tribunal other than a court, but the ultimate question of actual liability cannot be removed from the courts.'

Therefore, if the board denies the claimant's right to participate in the fund on any ground going to the basis of his claim, he may by filing an appeal and petition in the ordinary form be entitled to trial by jury, the case proceeding as any other suit.

It is not an appeal in the sense of appealing from one court to another, but is really the beginning of an original suit."

All compensation acts, whether of the form of the Washington, Ohio, Texas or German acts, or of the form of the Illinois, Wisconsin, California or English acts, are based upon the fundamental principles of taxation. They seek directly or indirectly to provide a fund to pay universal compensation to all injured workmen and their dependents by exacting a premium in the nature of a tax. In the case of the Ohio and German acts, the premium is a direct tax on the employer, and in the case of the British and Wisconsin acts, the compensation is paid through an indirect tax-by premiums to a liability insurance company. The creation and enforcement of such laws are by taxation through the exercise of the police powers vested in the legislature. Taxation may be by special assessment, assessment for general public purpose and by eminent domain. There must be a benefit flowing to the person taxed. In the case here discussed under the Texas Compensation Act, the benefit flowing to the employer is a discharge from suit. The benefit flowing to the employee is substantial, universal and certain compensation, in lieu of his expectancy in a suit at law. The magnitude of the compensation thus created can never be greater than the public purpose served, namely, to prevent dependents of the injured from becoming $a$ public charge.

ToLedo, OHIo.

JAS. HARrington Boyd. 